\title{
Larvicidal Activity in vivo of Ethanolic and Aqueous Extracts From Moringa (Moringa oleifera Lam.) on Aedes aegypti L. (Diptera: Culicidae)
}

\author{
Antonio Carlos Leite Alves ${ }^{1}$, Toshik Iarley da Silva ${ }^{1}$, Francisco Roberto de Azevedo ${ }^{2}$, Estelita Lima Cândido ${ }^{3}$, \\ Renata Rocha Virgulino ${ }^{3}$, Clarice E. T. L. Costa ${ }^{3} \&$ José Valmir Feitosa $^{2}$ \\ ${ }^{1}$ Department of Plant Science, Federal University of Viçosa, Viçosa, MG, Brazil \\ ${ }^{2}$ Center for Agricultural Sciences and Biodiversity, Federal University of Cariri, Crato, CE, Brazil \\ ${ }^{3}$ Medical School, Federal University of Cariri, Barbalha, CE, Brazil \\ Correspondence: Toshik I. da Silva, Department of Plant Science, Federal University of Viçosa, Viçosa, MG, \\ Brazil. E-mail: toshik.silva@ufv.br
}

Received: February 27, 2019 Accepted: April 7, $2019 \quad$ Online Published: June 15, 2019

doi:10.5539/jas.v11n8p129 URL: https://doi.org/10.5539/jas.v11n8p129

The research was financed by the National Council for Technological Development Scientific (CNPq) and Higher Education Personnel Coordination (CAPES).

\begin{abstract}
The insecticides properties of Moringa oleifera (moringa) were evaluated in Aedes aegypti larvae, throughout an entirely randomized trial, represented by ethanolic and aqueous extracts obtained from leaves, flowers, barks, seeds and moringa roots, besides the control group. Five batches of 10 in $3^{\text {rd }}$ stadium larvae were distributed in distilled water, added an extract concentration of $50 \mathrm{~mL} \mathrm{~L}^{-1}$, and the control treatment (distilled water). The test reading was measured after 24,48 and 72 hours after larvae exposure, were considered dead those who did not respond to a mechanical stimulation of a clamp. The seed ethanolic extract produced the best performance after 24 hours ( $34 \%$ mortality), but after 48 hours, the flower extract was the more potent ( $38 \%$ mortality). The largest larvicidal activity was observed with the extract concentration of $90 \mathrm{~mL} \mathrm{~L}^{-1}$. The results indicate that moringa has larvacides properties against Aedes, but its chemical constituents need to be isolated and tested separately to enhance your larvicidal activity.
\end{abstract}

Keywords: biolarvicides, vegetal extracts, white lily, culicidae

\section{Introduction}

Aedes aegypti $\mathrm{L}$. is one of the most important global public health vectors, it can transmit to man, the diseases yellow fever, dengue, chikungunya and zika. Among the arboviruses mentioned, dengue incidence has increased 30 -fold in the past 50 years, with increasing geographical expansion to new countries and zika which has been associated with several cases of Guillain-Barré syndrome and microcephaly in Brazil (WHO, 2012; WHO, 2017).

With the exception of yellow fever, which has a virus vaccine, the main strategy to combat other arboviruses is focused on vector elimination. Or reduction of infestation rates to very low levels, through the use of chemical insecticides as a priority measure. Currently, an integrated vector control has been adopted, bringing together various strategies, including educational, but ineffective in some countries.

In 2015, was first registered in Mexico a vaccine against dengue, but still there is no prediction to public distribution, leaving as main tool the vector control (Wichmann et al., 2017).

Studies show flaws of vector control method that prioritized the application of insecticides, due to the resistance developed by the vector, continuous dissemination and recurrence of epidemics (Lima et al., 2015). Added to these factors, the potential damage to human health and to the environment, caused by insecticides (Koul et al., 2008). Thus, various efforts have been made to search for alternatives and, including alternative control through vegetal bioactives (Garcez et al., 2013). 
Studies indicate the larvicidal activity of several vegetal extracts (Costa et al., 2013; Krinski et al., 2014; Silva et al., 2015). Among the researched vegetal species, M. oleifera Lam. is an Asian tree, widely cultivated in Brazil due to its low production cost and high adaptability to climate and soil conditions, it is not toxic to humans, (Coelho, 2007) and its larvicidal properties against $A$. aegypti have been proven in previous research (Ferreira et al., 2009; Santos et al., 2009; Coelho et al., 2009; Pontual et al., 2014).

Therefore, considering the well-known properties of moringa, our purpose was to evaluate the larvicidal activity of ethanolic and aqueous extracts from different parts of the plant on A. aegypti populations from Cariri, Ceará, Brazil.

\section{Materials and Methods}

\subsection{Egg Collection}

One hundred ovitraps has been installed in districts with high rates of vector infestation in Crato-CE, selected after consulting the A. aegypti Infestation Index Rapid Survey (LIRAa). The ovitraps were consisted of a black plastic cylinder container $(400 \mathrm{~mL}$ capacity) with a wooden paddle (Eucatex, $3 \times 11 \mathrm{~cm}$ ), fixed vertically inside for deposition of eggs, immersed in water. The installation of traps occurred at strategic locations of homes and collected five days later. The straws were brought to the laboratory of Agricultural Entomology of the Federal University of Cariri (UFCA) for identification and preparation of eggs for larvae hatching.

\subsection{Extracts Production}

Ethanolic and aqueous extracts were obtained from leaves, flowers, barks, seeds and roots of M. oleifera. Leaves and roots came from seedlings with 90 days, grown on the premises of the Institute Novo Sol (INSOL) in Juazeiro do Norte, Ceará. The remaining parts of the moringa were collected from adult plants also from the INSOL. The vegetal material was stored in a forced air circulation oven at $60^{\circ} \mathrm{C}$, until constant weight and it was subsequently milled. The powder was mixed with water and ethanolic at a concentration of $10 \%(\mathrm{w} / \mathrm{v})$, left to rest for 24 hours in the dark at ambient condition. Subsequently, the supernatant was separated by filtering, obtaining an aqueous and ethanolic extract at $10 \%(\mathrm{w} / \mathrm{v})$.

\subsection{Determination of Larvicidal Activity}

The experiments were conducted at the Entomology Agricultural Laboratory of UFCA, under controlled conditions of temperature $\left(25 \pm 1{ }^{\circ} \mathrm{C}\right)$, relative humidity $(70 \pm 10 \%)$ and 12-hour photoperiod in a chamber type B.O.D. during the period from February to May of 2016.

For each treatment (ethanolic and aqueous extract), five batches of third stadium larvae (L3) were introduced in disposable cups with capacity of $50 \mathrm{~mL}$ of distilled water. The extract was added to the vessel in a concentration of $50 \mathrm{~mL} \mathrm{~L}^{-1}$, with only distilled water as the remaining control. The test reading was measured after 24,48 and 72 hours after larvae exposure, were considered dead those who did not respond to a mechanical stimulation of a pipette, being observed the percentage of mortality. The treatments were conducted with five repetitions per each extract.

The experiments were, the best performance larvicide was reached with the ethanolic extract of moringa seed (24 hour exposure), various concentrations were tested, with a variation of 10 to $100 \mathrm{~mL} \mathrm{~L}^{-1}$, to identify the one that caused the higher mortality rate, and lethal concentrations. The trials were conducted according to the same criteria described above, this time with 11 treatments and 4 replications, totaling 44 experimental plots.

\subsection{Data Analysis}

The data were subjected to analysis of variance using the $\mathrm{F}$ test $(\mathrm{P}<0.05)$. The comparison of averages between extracts from different parts of the plant was done by Tukey test, at $5 \%$ probability. The data significant of the mortality at 24, 48 and 72 hours after exposure of the larvae were assessed by models of regression.

Subsequently, the data were subjected to analysis of variance using the $\mathrm{F}$ test $(\mathrm{P}<0.05)$. The comparison of averages between extracts from different parts of the plant was done by Tukey test, at $5 \%$ probability. If significant, effects of mortality at 24, 48 and 72 hours after exposure of the larvae were assessed by models of regression $(\mathrm{P}<0.05)$ represented by the equation: $\mathrm{y}=\mathrm{y}_{0}+\mathrm{ax}+\mathrm{bx}^{2}$, ethanolic extract of leaf and flower, where: $\mathrm{y}=$ response variable; $\mathrm{x}=$ hours after larvae exposure. While: $\mathrm{y}=\mathrm{y}_{0}+\mathrm{ax}$, for root and seed.

The mortality efficiency in the treatments of larvae control was determined in percentage through the Abbott formula (1925):

$$
\mathrm{E} \%=\frac{\mathrm{Nc}-\mathrm{Nt}}{\mathrm{Nc}} \times 100
$$


where, $\mathrm{E} \%=$ Mortality efficiency; $\mathrm{NC}=$ Number of alive individuals in the control treatment; $\mathrm{NT}=$ Number of alive individuals treated.

Lethal concentrations $\left(\mathrm{LC}_{10}, \mathrm{LC}_{50}\right.$ and $\left.\mathrm{LC}_{90}\right)$ in the seed ethanolic extract were determined by linear log-Probit regression, through StatPlus v5 program (Analyst Soft Inc.), significance level of 0.05.

\section{Results and Discussion}

\subsection{Larvicidal Activity of Ethanolic and Aqueous Extracts From Moringa oleifera}

The results show that the most potent extract came from the seed (Tables 1 and 2), resulting in larval mortality of $34 \%$, after 24 hours of exposure. The flower and root extracts resulted in $14 \%$ and $10 \%$ mortality rate. However, after 48 hours of exposure, the flower extract reached $38 \%$ mortality, a greater efficiency than that of the seed, resulting in $38 \%$ of mortality in the larvae, yet seed extract did not differ (Table 1).

Table 1. Average number, more or less, of dead larvae, the standard error and mortality efficiency of Aedes aegypti submitted to ethanolic extracts of moringa parts of plant at water concentration of $50 \mathrm{~mL} \mathrm{~L}^{-1}$

\begin{tabular}{|c|c|c|c|c|c|c|c|}
\hline \multirow{2}{*}{ Treatments } & \multicolumn{6}{|c|}{ Mortality/Efficiency (\%) } & \multirow{2}{*}{ Total Efficiency } \\
\hline & 24 hours & & 48 hours & & 72 hours & & \\
\hline Control & $0 \pm 0 \mathrm{c}$ & 0 & $0 \pm 0 \mathrm{c}$ & 0 & $0 \pm 0 \mathrm{a}$ & 0 & 0 \\
\hline Bark & $0 \pm 0 \mathrm{c}$ & 0 & $0 \pm 0 \mathrm{c}$ & 0 & $0 \pm 0 \mathrm{a}$ & 0 & 0 \\
\hline Leaf & $0.4 \pm 0.2 \mathrm{c}$ & 4 & $0.4 \pm 0.4 \mathrm{bc}$ & 4 & $0.2 \pm 0.2 \mathrm{a}$ & 2 & 10 \\
\hline Root & $1 \pm 0 \mathrm{~b}$ & 10 & $0.6 \pm 0.4 \mathrm{bc}$ & 6 & $0 \pm 0 \mathrm{a}$ & 0 & 16 \\
\hline Flower & $1.4 \pm 0.5 \mathrm{~b}$ & 14 & $3.8 \pm 1.1 \mathrm{a}$ & 38 & $1 \pm 0.4 \mathrm{a}$ & 10 & 62 \\
\hline Seed & $3.4 \pm 0.5 \mathrm{a}$ & 34 & $2.2 \pm 0.6 \mathrm{a}$ & 22 & $0.6 \pm 0.4 \mathrm{a}$ & 6 & 62 \\
\hline $\mathrm{CV}(\%)$ & 15.5 & - & 24.2 & - & 19.4 & - & - \\
\hline
\end{tabular}

Note. Means followed by the same letter do not differ from each other by the Tukey test at $5 \%$ probability.

Table 2. Average number, more or less, of dead larvae, the standard error and mortality efficiency of Aedes aegypti subjected to aqueous extracts of moringa parts of plant at water concentration of $50 \mathrm{~mL} \mathrm{~L}^{-1}$

\begin{tabular}{llllllll}
\hline \multirow{2}{*}{ Treatments } & \multicolumn{7}{c}{ Mortality/Efficiency (\%) } \\
\cline { 2 - 7 } & 24 hours & 48 hours & 72 hours \\
\hline Control & $0 \pm 0 \mathrm{~b}$ & 0 & $0 \pm 0 \mathrm{~b}$ & 0 & $0 \pm 0 \mathrm{a}$ & 0 & 0 \\
Bark & $0 \pm 0 \mathrm{~b}$ & 0 & $0 \pm 0 \mathrm{~b}$ & 0 & $0 \pm 0 \mathrm{a}$ & 0 & 0 \\
Leaf & $0.6 \pm 0.2 \mathrm{~b}$ & 6 & $0 \pm 0 \mathrm{~b}$ & 0 & $0.2 \pm 0.2 \mathrm{a}$ & 2 & 8 \\
Root & $0.2 \pm 0.2 \mathrm{~b}$ & 2 & $0.2 \pm 0.2 \mathrm{ab}$ & 2 & $0 \pm 0 \mathrm{a}$ & 0 & 4 \\
Flower & $0.8 \pm 0.6 \mathrm{~b}$ & 8 & $0 \pm 0 \mathrm{~b}$ & 0 & $0 \pm 0 \mathrm{a}$ & 0 & 8 \\
Seed & $2.4 \pm 0.7 \mathrm{a}$ & 24 & $0.6 \pm 0.7 \mathrm{a}$ & 6 & $1 \pm 0 \mathrm{a}$ & 10 & 40 \\
CV $(\%)$ & 22.13 & - & 11.33 & - & 7.46 & - & -
\end{tabular}

Note. Means followed by the same letter do not differ from each other by the Tukey test, at $5 \%$ probability.

After 72 hours of exposure, the treatments did not differ, but again the flower and seed extracts has obtained the higher mortality rate, $10 \%$ and $6 \%$, respectively. The vegetal insecticides generally exhibit rapid degradation in the environment, many applications may be required to obtain a satisfactory control (Morais \& Marinho-Prado, 2016). Probably, during the exposure period, the extracts lost their insecticidal activity due to the increased time of exposure to light on the molecules (not synthetic), causing to be unstable in the environment with low residual power. Considering overall efficiency of three exposure periods, both seed and flower extracts showed the same mortality efficiency $(62 \%)$ (Table 1).

Figure 1 illustrates the relationship between $A$. aegypti larvae mortality percentage subjected to ethanolic extracts of flower, seed, leaf and root from $M$. oleifera and the hours after larvae exposure. It is noticed a quadratic relationship between the evaluation time and ethanolic extracts of flower and leaf, and linear correlations between the seed and root extracts. The moringa seeds contains, besides lectins, glycoproteins of nonimmune origin, which bind carbohydrates by two binding sites, agglutination of animal cells and/or vegetables, 
precipitating polysaccharides, glycoproteins or glycolipids. In addition, moringa has insecticidal activity, and is not toxic to humans (Coelho, 2014).

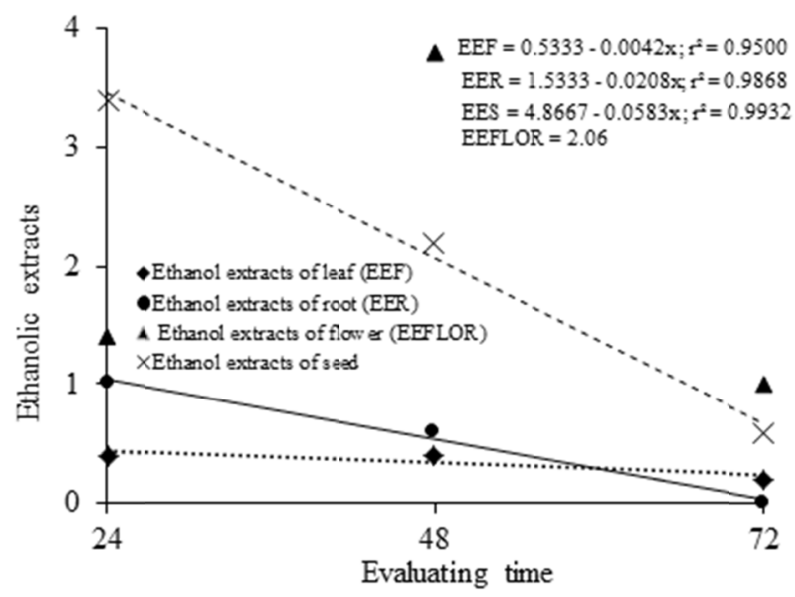

Figure 1. Relation between Aedes aegypti larvae mortality percentage subjected to ethanolic extracts of flower, seed, leaf and root from Moringa oleifera and the hours after larvae exposure

The lectins of $M$. oleifera were effective in controlling the larvae of $A$. aegypti, the insect stops its digestion and absorption of nutrients, thus causing death by malnutrition (Santos et al., 2009). These M. oleifera lectins were also efficient in the developmental delay and mortality of $A$. aegypti larvae, since it was detected hemagglutination activity was detected in the extracts, suggesting that soluble lectin helps delay larval development and increases insectmortality (Coelho et al., 2009).

Agra-Neto (2014) when testing water-soluble moringa lectins (WSMoL) and coagulants (cMoL), which are supposed to be responsible for the larvicidal effect of the extract derived from the moringa seed, it was observed in strains of $A$. aegypti larvae organophosphates-susceptible in L4 stage, that the larvicidal activity WSMoL reached $51.6 \%$ rates. Distinctly, cMoL did not cause mortality in susceptible larvae to that insecticide group at L4 stage. The larval mortality resistant to such products has not been achieved by WSMol or cMoL. In the present study the mortality rate was lower, presumably because water-soluble moringa lectins or the coagulant were not isolated.

Analyzing larvicidal effect of methanolic extracts obtained from seeds of Persea americana on A. aegypti, Agrela et al. (2014), after 24 hours of larvae exposure to the extract at concentrations of 25 and $50 \mathrm{mg} \mathrm{L}^{-1}$, obtained a $100 \%$ mortality of larvae exposed.

Costa et al. (2013) also observed the biocidal effect of seeds extracts from Annona crassiflora, A. dioica, A. mucosa, A. coriacea e Cardiopetalum calophyllum on A. aegypti larvae. A. coriacea in methanol and hexane, and $A$. mucosaem in methanol $\left(0.1 \mathrm{mg} \mathrm{mL}^{-1}\right)$ caused $100 \%$ mortality. A. crassiflora $\left(1 \mathrm{mg} \mathrm{mL}^{-1}\right)$ caused mortality higher than $90 \%$ with crude methanol extract, hexanic, dichloromethane and hexanic fraction. The hydroalcoholic fractions, ethyl acetate and chloroform had not insecticidal activity. The crude extract of $A$. dioicae C. calophyllumcom species had a mortality less than $50 \%$. Therefore, methanol and hexane of $A$. crassiflora, A. coriaceae A. mucosaem are promising in developing future biocides for dengue vector control.

Considering the mortality percentage for each treatment in relation to the total number of dead larvae in the trial, the treatments with ethanolic extract of the seed and flower represent each, $41 \%$ of killed larvae, followed by root (11\%). The control treatment and moringa bark extract showed no larvicidal activity (Figure 2). 


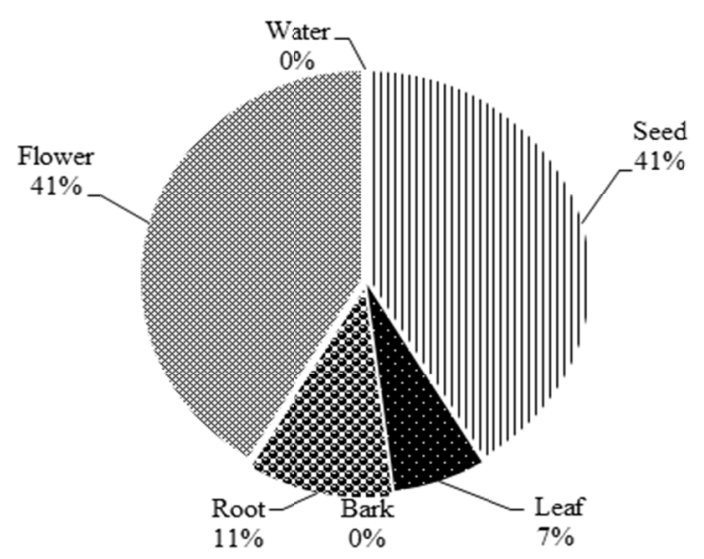

Figure 2. Percentage distribution of Aedes aegypti larvae mortality subjected to ethanolic extracts from different parts (bark, flower, seed, leaf and root) of Moringa oleifera

A comparison of both ethanolic extract and aqueous extract, the latter showed superior performance. It was found that seed aqueous extract had shown the highest average (4) and larvae mortality efficiency $(40 \%)$ in three analyses, differed statistically from other moringa parts. When comparing tables 1 and 2, can be observed that the seed aqueous extract efficiency suffered a reduction of $22 \%$ when compared with the ethanolic extract. Even greater reduction was observed in the flower water extract, which was $54 \%$ less efficient than the ethanolic extract.

Ferreira et al. (2009), evaluated the potential of aqueous extract of moringa seeds on A. aegypti larvae in concentration of $5.2 \mathrm{~g} \mathrm{~mL}^{-1}$, and observed a mortality rate of $99.2 \%$ in 24 hours and toxic, as well as effects were observed at lower concentrations, showing an upward progression in larval death.

Pontual (2010), evaluated the larvicidal activity in different concentrations of aqueous extract of $M$. oleifera flowers on A. aegypti L4 larvae, and observed that in the highest concentration $\left(2.4 \mathrm{mg} \mathrm{mL}^{-1}\right)$ caused a mortality of almost $90 \%$ of the larvae. While the water extract was not as efficient in this research, causing $8 \%$ mortality.

Pontual et al. (2014) indicates that, the flower water extract of this plant is a new biodegradable tool because it contains the MoFTI, which is a protein that inhibits trypsin in the larvae intestine of this vector, almost reaching $20 \%$ mortality.

It was observed that the percentage of mortality for each treatment, in relation to the total number of dead larvae in the experiment represented by aqueous extract from moringa different parts, was similar to percentage calculation of mortality in ethanolic extract. The treatments represented by control (only water) and bark water extract has caused no mortality, while seed extract caused the highest mortality rate $(60 \%)$ of the dead larvae in this assay, followed by flower with $16 \%$, that was not as efficient as in ethanolic extract (Figure 3). 


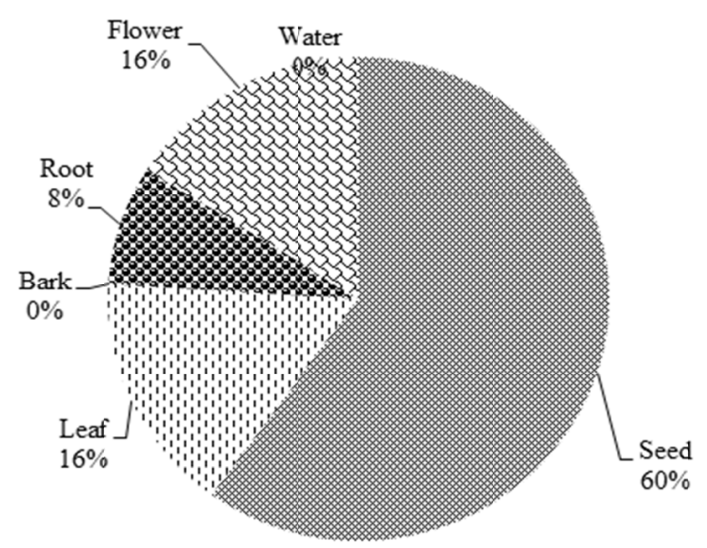

Figure 3. Percentage distribution of Aedes aegypti larvae mortality subjected to ethanolic extracts from different parts (bark, flower, seed, leaf and root) of Moringa oleifera

\subsection{Larvicidal Activity in Different Concentrations of Ethanolic Extract of Moringa oleifera Seed}

The ethanolic extract of $M$. oleifera seeds caused toxic effect to $A$. aegypti larvae. According to log Probit analysis, defined $\mathrm{LC}_{50}$ at $50.28 \mathrm{~mL} \mathrm{~L}^{-1}$ concentration, featuring this product as promising biolarvicide. The minimum concentration capable of mortality $\left(\mathrm{LC}_{10}\right)$ is $31.62 \mathrm{~mL} \mathrm{~L}^{-1}$ and the maximum toxicity $\left(\mathrm{LC}_{90}\right)$ is 79.96 $\mathrm{mL} \mathrm{L}^{-1}$, i.e. the concentration necessary to cause the death of $90 \%$ of the larvae (Table 3 ).

Table 3. Lethal concentrations (LC) of ethanolic extract of Moringa seed on Aedes aegypti larvae

\begin{tabular}{llll}
\hline Specie & $\mathrm{LC}_{10}$ & $\mathrm{LC}_{50}$ & $\mathrm{LC}_{90}$ \\
\hline Moringa oleifera & 31.62 & 50.28 & 79.96 \\
Confidence Intervals (0.05) & $0.69-1443.9$ & $6.18-409.24$ & $4.43-1443.22$ \\
\hline
\end{tabular}

Guerrero et al. (2015), studying the toxicity of extracts from native plants of Mexico against $A$. aegypti larvae, determined actual values $\mathrm{LC}_{50}$ of Argemone mexicana seeds, using acetone and hexane as solvents, 60 and 100 $\mathrm{mg} / \mathrm{mL}$ after 24 hours post-exposure and 50 and $80 \mu \mathrm{g} \mathrm{mL}^{-1}$ after 48 hours, respectively.

Evaluating larvicidal activity of ethanolic extract of $H$. oppsitifolia on A. aegypti, Londoño et al. (2013), Confirmed $\mathrm{LC}_{50}$ e $\mathrm{LC}_{90}$ values in 24 hours of larvae exposure, 41 and $80 \mathrm{ppm}$, respectively. When lethal concentrations were observed in 48 hours of exposure, there has been changes to $\mathrm{LC}_{50}$ e $\mathrm{LC}_{90}$ values, which are 39 and $77 \mathrm{ppm}$, respectively. Thereby, we can observe an increase in larvicidal effectiveness over time, because it took a lower concentration of the extract to kill the same amount of larvae.

The analyze of the larvicidal activity of ethanolic extract in different concentrations of moringa seed on $A$. aegypti larvae, showed the low mortality until the dosage of $70 \mathrm{~mL}$, not differ statistically when exposed to 24 hour period. The mortality increased, from $80 \mathrm{~mL}$ dosage to $100 \mathrm{~mL}$, to $97.5 \%$ (Table 4). 
Table 4. Average number, more or less, of dead larvae, the standard error and mortality efficiency of Aedes aegypti subjected to ethanolic extracts of moringa seed at different concentrations

\begin{tabular}{|c|c|c|c|c|c|c|c|}
\hline \multirow{2}{*}{ Treatment $\left(\mathrm{mL} \mathrm{L}^{-1}\right)$} & \multicolumn{6}{|c|}{ Mortality/Efficiency (\%) } & \multirow{2}{*}{ Total Efficiency } \\
\hline & 24 hours & & 48 hours & & 72 hours & & \\
\hline Control & $0^{1} \pm 0 \mathrm{~d}$ & 0 & $0 \pm 0 \mathrm{~b}$ & 0 & $0 \pm 0 \mathrm{a}$ & 0 & 0 \\
\hline 10 & $0.25 \pm 0.3 \mathrm{~d}$ & 2.5 & $0 \pm 0 \mathrm{~b}$ & 0 & $0 \pm 0 \mathrm{a}$ & 0 & 2.5 \\
\hline 20 & $0 \pm 0 \mathrm{~d}$ & 0 & $0 \pm 0 \mathrm{~b}$ & 0 & $0 \pm 0 \mathrm{a}$ & 0 & 0 \\
\hline 30 & $0 \pm 0 \mathrm{~d}$ & 0 & $0.25 \pm 0.3 \mathrm{c}$ & 2.5 & $0 \pm 0 \mathrm{a}$ & 0 & 2.5 \\
\hline 40 & $0.5 \pm 0.3 \mathrm{~d}$ & 5 & $1.25 \pm 0.8 \mathrm{ab}$ & 12.5 & $0.75 \pm 0.5 \mathrm{a}$ & 7.5 & 25 \\
\hline 50 & $1.5 \pm 0.9 \mathrm{~cd}$ & 15 & $2.25 \pm 0.5 \mathrm{abc}$ & 22.5 & $0.75 \pm 0.3 \mathrm{a}$ & 7.5 & 45 \\
\hline 60 & $0.25 \pm 0.3 \mathrm{~cd}$ & 2.5 & $4.50 \pm 1.0 \mathrm{a}$ & 45 & $1.25 \pm 0.5 \mathrm{a}$ & 12.5 & 60 \\
\hline 70 & $4.25 \pm 1.1 \mathrm{bc}$ & 42.5 & $3.50 \pm 0.6 \mathrm{ab}$ & 35 & $0.50 \pm 0.3 \mathrm{a}$ & 5 & 82.5 \\
\hline 80 & $5.0 \pm 1.6 \mathrm{bc}$ & 50 & $3.50 \pm 1.0 \mathrm{ab}$ & 35 & $0.75 \pm 0.5 \mathrm{a}$ & 7.5 & 92.5 \\
\hline 90 & $7.5 \pm 1.3 \mathrm{ab}$ & 75 & $2.25 \pm 1.0 \mathrm{abc}$ & 22.5 & $0.25 \pm 0.3 \mathrm{a}$ & 2.5 & 100 \\
\hline 100 & $9.75 \pm 0.3 \mathrm{a}$ & 97.5 & $0.25 \pm 0.3 \mathrm{c}$ & 2.5 & $0 \pm 0 \mathrm{a}$ & 0 & 100 \\
\hline $\mathrm{CV}(\%)$ & 21.56 & - & 22.49 & - & 18.81 & - & - \\
\hline
\end{tabular}

Note. Means followed by the same letter do not differ significantly from each other by the Tukey test, at $5 \%$ probability.

However, in 48 and 72 hours of exposure, there was a decrease in mortality of the larvae from the $70 \mathrm{~mL}$ dosage. But, considering the overall efficiency for the three periods of exposure, it is observed that, from $60 \mathrm{~mL}$ dosage of ethanolic extract of moringa seed, it achieves a mortality above $50 \%$. It can observe a positive relationship between dosage and mortality increase, reaching $100 \%$ mortality at dosage of 90 and $100 \mathrm{~mL} \mathrm{~L}^{-1}$ (Table 4). Already, dosages below this value cause low mortality to insect vector. Ferreira et al. (2009) observed the activity larvicidal activity in concentrations of $375,750,1,300,2,600$ and $5,200 \mu \mathrm{g} \mathrm{mL}^{-1}$ of aqueous extract of moringa seed, when the extract concentration was increased, had a proportional increase in average of dead larvae, corroborating the present research.

Figure 4 presents A. aegypti larvae mortality in function of different concentrations of ethanolic extract of moringa seed, confirming the relationship between concentration and mortality, given that full average reaches at the concentration of $90 \mathrm{~mL} \mathrm{~L}^{-1}$. You can also see that the mortality peak begins to lean on the chart from the concentration of $40 \mathrm{~mL} \mathrm{~L}^{-1}$, where mortality efficiency was $25 \%$.

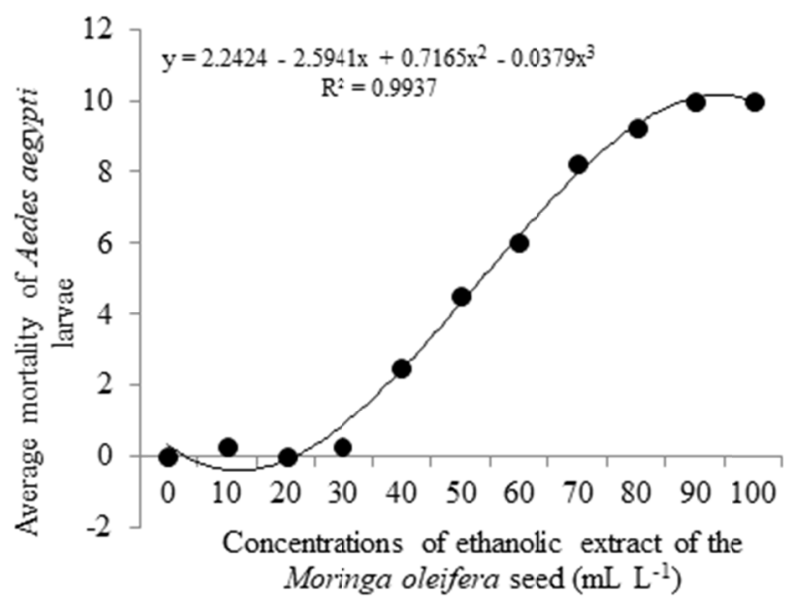

Figure 4. Mortality analysis of Aedes aegypti larvae exposed to different concentrations of ethanolic extract of Moringa oleifera seed

It is observed the low effectiveness of the seed ethanolic extract in lower concentrations, not observed significant differences in concentrations of 10, 20,30 $\mathrm{mL} \mathrm{L}^{-1}$, where almost there was not mortality (Figure 4). 
Studying the mortality efficiency of essential oil concentrations, on larvae of A. aegypti, Silva et al. (2017), obtained data behavior similar to those obtained in this study, where the increase in the concentration of the product resulted in a greater control efficiency of larvae of this vector.

\section{Conclusions}

Moringa has larvicidal activity against Aedes aegypti until 48 hours of exposure. The greatest bioactives concentration seems to be present in seeds and flowers, because get better results with extracts produced with those parts. Aqueous extracts are less efficient in the control, even seed made. It is believed that the isolation of plant constituents can guide further research on the persistence and influence increase of environmental conditions.

\section{References}

Abbott, W. S. (1925). A method of computing the effectiveness of an insecticide. Journal of Economic Entomology, 18, 265-267. https://doi.org/10.1093/jee/18.2.265a

Agra Neto, A. C. (2014). Evaluation of insecticidal activity of aqueous extract and water-soluble lectin from Moringa oleifera seeds against Sitophilus zeamais (Thesis Doctorate in Biological Sciences, Biological Sciences Center, Federal University of Pernambuco, Recife).

Agrela, I. F., Hidalgo, Y., \& Herrera, F. (2014). Efecto larvicida de extractos metanólicos obtenidos de semillas y hojas de Persea americana (Laurales: Lauraceae) (aguacate) sobre Aedes aegypti (Diptera: Culicidae). Boletín de Malariología y Salud Ambiental, 2, 199-207.

Coelho, J. S., Santos, N. D. L., Napoleão, T. H., Gomes, F. S., Ferreira, R. S., Zingali, R. B.,... Paiva, P. M. G. (2009). Effect of Moringa oleifera lectin on development and mortality of Aedes aegypti larvae. Chemosphere, 77, 934-938. https://doi.org/10.1016/j.chemosphere.2009.08.022

Coelho, J. S. (2007). Atividade hemaglutinante e larvicida (Aedes aegypti) na água tratada com sementes de Moringa oleifera. (Hemagglutinating and larvicidal activity (Aedes aegypti) in water treated with Moringa oleifera seeds (Master's Thesis in Biochemistry, Biological Sciences Center, Federal University of Pernambuco, Recife).

Costa, M. S., Pereira, M. J. B., Oliveira, S. S., Souza, P. T., Dall'oglio, E. L., \& Alves, T. C. (2013). Annonaceae cause mortality in Aedes aegypti (Linnaeus, 1762) (Diptera: Culicidae). Revista Brasileira de Biociencias, 11(2), 184-190.

Ferreira, P. M. P., Carvalho, A. F. U., Farias, D. F., Cariolano, N. G., Melo, V. M. M., Queiroz, M. G. R.,... Machado-Neto, J. G. (2009). Larvicidal activity of the water extract of Moringa oleifera seeds against Aedes aegypti and its toxicity upon laboratory animals. Anais da Academia Brasileira de Ciências, 81(2), 207-216. https://doi.org/10.1590/S0001-37652009000200007

Garcez, W. S., Garcez, F. R., Silva, L. M. G. E., \& Sarmento, U. C. (2013). Naturally occurring plant compounds with larvicidal activity against Aedes aegypti. Revista Virtual de Química, 5(3), 363-393. https://doi.org/ 10.5935/1984-6835.20130034

Guerrero, R. R., Pérez, M. A. R., \& Campos, M. N. (2015). Toxicity of Mexican native plant extracts against larvae of Aedes aegypti (Diptera: Culicidae). Asian Pacific Journal of Tropical Biomedicine, 5(4), $287-291$. https://doi.org/10.1016/S2221-1691(15)30347-6

Koul, O., Walia, S., \& Dhaliwal, G. S. (2008). Essential oils as green pesticides: Potential and constraints. Biopesticides International, 4, 63-84.

Krinski, D., Massaroli, A., \& Machado, M. (2014). Insecticidal potential of the Annonaceae family plants. Revista Brasileira de Fruticultura, 36, 225-242. https://doi.org/10.1590/S0100-29452014000500027

Lima, E. P., Goulart, M. O. F., \& Rolim Neto, M. L. (2015). Meta-analysis of studies on chemical, physical and biological agents in the control of Aedes aegypti. BMC Public Health, 15, 858. https://doi.org/10.1186/ s12889-015-2199-y

Londoño, J. C. Á., Gandica, I. D., Obando, O. A. A., \& Montoya, J. A. J. (2013). Control del vector del dengue utilizando fracciones etéreas de plantas (Asteraceae) como larvicidas. Revista Salud Pública, 15(2), 227-236.

Morais, L. A. S., \& Marinho-Prado , J. S. (2016). Plantas com atividade inseticida. In B. A. Halfeld-Vieira, J. S. Marinho-Prado, K. L. Nechet, M. A. B. Morandi, \& W. Bettiol (Eds.), Defensivos agrícolas naturais: Uso e perspectivas (Cap. 19, pp. 542-593). 
WHO. (2012). Handbook for integrated vector management. Geneva, Switzerland: World Health Organization.

WHO. (2017). Enfermedad por el virus de Zika. Retrieved from http://www.who.int/mediacentre/factsheets/ zika/en

Wichmann, O., Vannice, K., Asturias, E. J., Luna, E. J. A., Longini, I., Lopez, A. L., ... Hombach, J. (2017). Live-attenuated tetravalent dengue vaccines: The needs and challenges of post-licensure evaluation of vaccine safety and effectiveness. Vaccine, 35, 5535-5542. https://doi.org/10.1016/j.vaccine.2017.08.066

Pontual, E. V. (2010). Extracts from Moringa oleifera flowers: Effect of larvicidal on gut trypsin acethylcholinesterase activity from Aedes aegypti larvae (Master's Thesis in Biochemistry and Physiology, Biological Sciences Center, Federal University of Pernambuco, Recife).

Pontual, E. V., Santos, N. D. L., Moura, M. C., Coelho, L. C. B. B., Navarro, D. M. A. F., Napoleão, T. H., \& Paiva, P. M. G. (2014). Trypsin inhibitor from Moringa oleifera flowers interferes with survival and development of Aedes aegypti larvae and kills bacteria inhabitant of larvae midgut. Parasitology Research, 113, 727-733. https://doi.org/10.1007/s00436-013-3702-y

Santos, A. F. S., Luz, L. A., Argolo, A. C. C., Teixeira, J. A., Paiva, P. M. G., \& Coelho, L. C. B. B. (2009). Isolation of a seed coagulante Moringa oleifera lectin. Process Biochemistry, 44, 504-508. https://doi.org/ 10.1016/j.procbio.2009.01.002

Silva, P. C. B., Santos, J. C., Santos, G. K. N., Dutra, K. A., Santana, A. L. B. D., Maranhao, C. A., ... Bieber, L. W. (2015). Extract of Bowdichia virgilioides and maackiain as larvicidal agente against Aedes aegypti mosquito. Experimental Parasitology, 153, 160-164. https://doi.org/10.1016/j.exppara.2015.03.018

Silva, T. I., Alves, A. C. L., Azevedo, F. R., Marco, C. A., Santos, H. R., \& Azevedo, R. (2017). Larvicide activity of essential oils on Aedes aegypti L. (Díptera: Culicidae). Idesia (Arica), 35(2), 63-70. https://doi.org/10.4067/S0718-34292017005000026

\section{Copyrights}

Copyright for this article is retained by the author(s), with first publication rights granted to the journal.

This is an open-access article distributed under the terms and conditions of the Creative Commons Attribution license (http://creativecommons.org/licenses/by/4.0/). 